\title{
A palynostratigraphic study of the Umrer Coalfield of Wardha Basin, Maharashtra State, Central India and its putative correlation with Indian and other Gondwanan areas
}

\author{
Estudo palinoestratigráfico da região carvoeira da Bacia de Wardha, Estado de \\ Maharashtra, Índia Central, e sua provável correlação com palinoestratigrafias \\ gondvânicas indianas e de outras áreas \\ Pauline Sabina Kavali ${ }^{1,2}$, Mahesh Shivanna ${ }^{3}$, Mahesh Bilwa Lingappa ${ }^{4}$ and \\ Mary Elizabeth Cerruti Bernardes-de-Oliveira ${ }^{2}$ \\ 'Birbal Sahni Institute of Palaeosciences, 53 University Road, Lucknow 226007, India (paulinesabina@gmail.com) \\ 2Universidade de São Paulo - USP, Instituto de Geociências, Departamento de Geologia Sedimentar e Ambiental - GSA, \\ Laboratório de Paleobotânica e Palinologia, Programa de Pós-graduação em Geoquímica e Geotectônica, Rua do Lago, 562, \\ CEP 05508-080, São Paulo, SP, Brazil (maryeliz@usp.br) \\ ${ }^{3}$ Universidade Federal do Rio Grande do Sul - UFGRS, Instituto de Geociências, Porto Alegre, RS, Brazil \\ (mahesh.shivanna@ufrgs.br) \\ ${ }^{4}$ University of Mysore, Department of Studies in Geology, Karnataka, India (mbilwa@rediffmail.com)
}

Received on April 1't 2016 ; accepted on September 22 $2^{\text {th }}, 2016$

\begin{abstract}
The present work details the results of the palynological studies carried out in the Umrer Coalfield of Wardha Basin of Maharashtra State, Central India. The coalfield covers an area of $4 \mathrm{sq} . \mathrm{km}$ and is characterized by three coal seams designated as bottom, middle and top seams with partings. Statistical analysis of the palynomorphs from these sediments have revealed the dominance of radial monosaccate pollen grains of the genus Parasaccites and subdominance of non-striate bisaccate genus Scheuringipollenites in association with other typical early Permian taxa viz. Crucisaccites, Callumispora, Caheniasaccites, Brevitriletes, Tiwariasporis and Primuspollenites. This association characterizes the palynoflora of the upper Karharbari Formation of India on the basis of which the Umrer Coalfield has been assigned an early Permian late Sakmarian to early Artinskian age. It is further authenticated by the presence of the species Crucisaccites monoletus significant of the Karharbari Formation. Age deductions have also been made by correlations with similar assemblages from different basins in India and early Permian palynoflora from other Gondwanan continents some of which have been associated with radiometrically dated sediments.
\end{abstract}

Keywords: Umrer Coalfield; India; Early permian; Palynology.

\section{Resumo}

Este trabalho relata os resultados dos estudos palinológicos realizados na região carvoeira da Bacia de Wardha, no Estado de Maharashtra, Índia Central. A região carvoeira cobre uma área de $4 \mathrm{~km}^{2}$ e é caracterizada por três camadas de carvão designadas como camadas de base, meio e topo intercaladas com lâminas de sedimento. Análises estatísticas dos palinomorfos desses sedimentos tem evidenciado o domínio de grãos de pólen monossacados radiais do gênero Parasaccites e subdomínio de bissacados estriados do gênero Scheuringipollenites em associação com outros taxa típicos do Eopermiano, a saber: Crucisaccites, Callumispora, Caheniasaccites, Brevitriletes, Tiwariasporis e Primuspollenites. Esta associação caracteriza a palinoflora da Formação Karharbari superior, sugerindo ser a região carvoeira de Umrer de idade neossakmariana a eoartinskiana. Essa idade é confirmada pela presença da espécie Crucisaccites monoletus típica da Formação Karharbari. Deduções de idade tem também sido feitas por correlações com assembleias similares de diferentes bacias da Índia e de palinofloras eopermianas de outros continentes gondvânicos, alguns dos quais tem sido associados com sedimentos datados radiométricamente.

Palavras-chave: Mina de carvão Umrer; Índia; Permiano inferior; Palinologia. 


\section{INTRODUCTION}

The Gondwana sediments in India are exposed and spread over an enormous extent of 50,000 sq.km and collectively represent about $6000 \mathrm{~m}$ of strata. The Gondwana basins of Peninsular India show certain specific characteristics in terms of their distribution pattern and mode of evolution. These occur as conspicuous rectilinear belts of basins of failed rift origin (Figure 1). These basins were embryonic in dimension during initial stage of Gondwana deposition i.e. during the Talchir Period (= to the Darwin Tillite Formation of South Victoria Land, Antarctica (Kyle, 1977); Dwyka Formation of Karoo Basin, South Africa (Anderson, 1977); Stockton Formation of Collie Basin and Nangetty Formation of North Perth Basin of Australia (Backhouse, 1991, 1993) and uppermost Itararé Group of Paraná Basin, Brazil (Souza, 2006), where sedimentation commenced with the deposition of glaciogene, fluvio-lacustrine and/or marine sediments. Evidently, the growth of these sediments continued through a regional tensional regime, the basins being characterized by extensional faulting parallel to the rift trend creating half-grabens that formed different sub basins within the master basin belt (Acharyya, 2000). The Gondwana Coal Basins in India are generally located along the present river valleys after which they are usually named. They include NW- SE trending Wardha - Godavari Basin and Son-Mahanadi Basin, E-W oriented Koel-Damodar and Satpura Basin and N-S trending Rajmahal Basin (Figure 1A).

The Wardha Basin is the NW extension of the Godavari Basin. There are four major coal bearing areas in this basin viz. Bandar Coalfield, Wardha Valley Coalfield, Kamptee Coalfield and Umrer Coalfield (Figure 1B).

The present work discusses the palynological studies carried out in the Umrer Coalfield of the Wardha Basin. The first palynological report from the Umrer Coalfield was by Bharadwaj and Anand-Prakash (1974), the next being by Jha et al. (2007). Palynological studies were carried out by Jha et al. (2007) only in the middle seam of the three seams recognized by Raja Rao (1982) in the Umrer Coalfield where they have reported palynoflora characteristic of the Upper Karharbari Formation (Late Sakmarian). Their findings corroborated with that of Bharadwaj and Anand-Prakash (1974). They also reported equisetalean axes from those sediments. This work presents the results of the palynological studies carried out in the associated sediments of the three seams viz. bottom, middle and top seams. The seams were devoid of spores and pollen but were in rich organic matter which were analysed to interpret the depositional setting of the coalfield (Pauline Sabina et al., 2010). Here we deal with the palynology of the associated sediments, the biostratigraphic aspects of the study comprising palynozonation and palynodating based on interbasinal palynostratigraphic correlation as well as across the Gondwana. This is a concise presentation of a part of the Ph.D. thesis of the first author (Kavali, 2008). Kalkar et al. (2010) reported Late Permian palynoflora from a younger seam over the top seam exposed in the Makhardohkra area which is the lateral extension of the Umrer Coalfield. This seam is absent in the Umrer Coalfield. Apart from these studies, Agashe (1979) and Tewari et al. (2004) reported

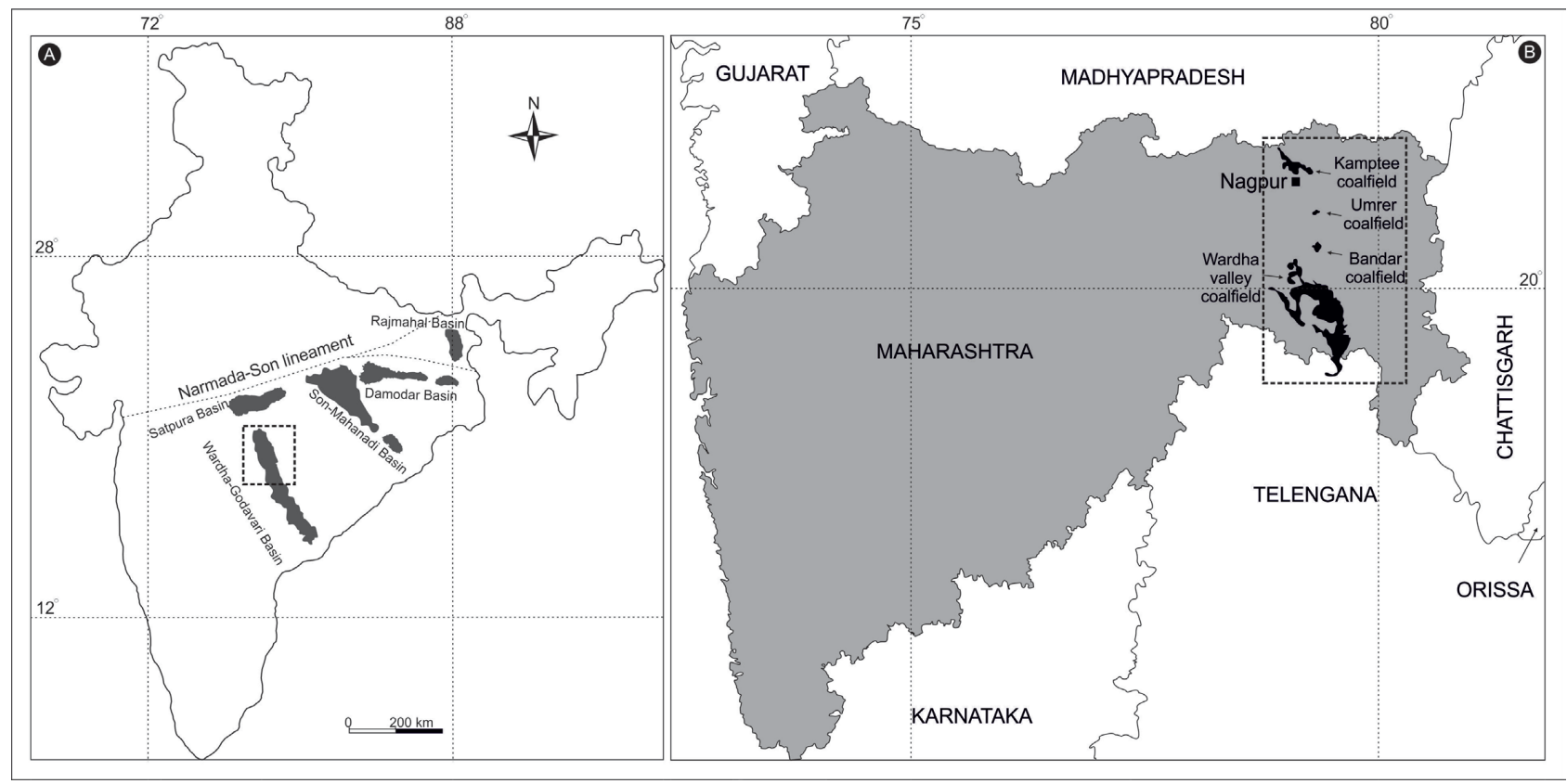

Figure 1. (A) Map showing the Gondwana Basins of India; (B) Location map of the coal bearing areas in the Wardha Basin. 
megaspores, Sundaram and Nandi (1984) and Tewari et al. (2012a) reported macroflora and gymnosperm seeds were reported by Tewari et al. (2012b) from the Umrer Coalfield. Other palynological and related works in the Wardha Basin are that of Agashe and Chitnis $(1970,1972)$, Bhattacharrya (1997), Tewari (2008), Mahesh et al. (2008, 2011, 2014) and Jha et al. (2011) from the Wardha Valley Coalfield; Pauline Sabina et al. (2007) from the Bandar Coalfield and Tewari (2007) from the Kamptee Coalfield.

\section{Wardha Basin}

The Wardha Basin is situated in the State of Maharashtra, Central India. It is the Northwestern extension of the Godavari Basin of the state of Telangana (formerly part of the state of Andhra Pradesh) covering an area of about 4150 sq.km. The Gondwana sediments exposed in the state of Maharashtra constitute the main part of the Wardha Basin and are mostly confined to the northeastern part of the state in the districts of Nagpur, Chandrapur and Yavatmal (Figure 1B). The Gondwana sediments comprise the Talchir, Barakar, Kamthi and Maleri formations resting over the Archaean gneisses and Proterozoic Pakhal and Sullavai sequences that constitute the basement. After the cessation of Gondwana sedimentation there was an occurrence of marine incursion in the form of Bagh and Lameta beds in parts of Nagpur and Chandrapur districts.
This was followed by the voluminous outpouring of lava during the Upper Cretaceous Period. These lava flows were termed as Deccan traps which cover two thirds of the state of Maharashtra. It is the second most extensive geological formation in Peninsular India next to the Archaean igneous and metamorphic complex.

\section{LOCATION AND GEOLOGY OF THE UMRER COALFIELD}

The Umrer Coalfield lies in the Wardha Basin. It is situated about $44 \mathrm{~km}$ southeast of Nagpur district of Maharashtra state. The present investigation covers an area of $4 \mathrm{sq}$. $\mathrm{km}$ and lies between latitudes $20^{\circ} 50^{\prime} 45^{\prime \prime} \mathrm{N}$ and $20^{\circ} 52^{\prime} 50^{\prime \prime} \mathrm{N}$ and longitudes $79^{\circ} 16^{\prime} \mathrm{E}$ and $79^{\circ} 18^{\prime} 30^{\prime \prime} \mathrm{E}$. (Figure 2).

The coal bearing area lies to the west of the Umrer town and is covered by thick black cotton soil with sporadic occurrence of a few outcrops of Lameta Formation. The stratigraphical sequence of the Umrer coalfield, after Raja Rao (1982), is given in Table 1.

According to Raja Rao (1982) it is composed of the following lithology from bottom to top:

Archaean Sequence - the metamorphic rocks of Sakoli group constitute the Archaean sequence and are represented by quartz-mica schists and phyllites.

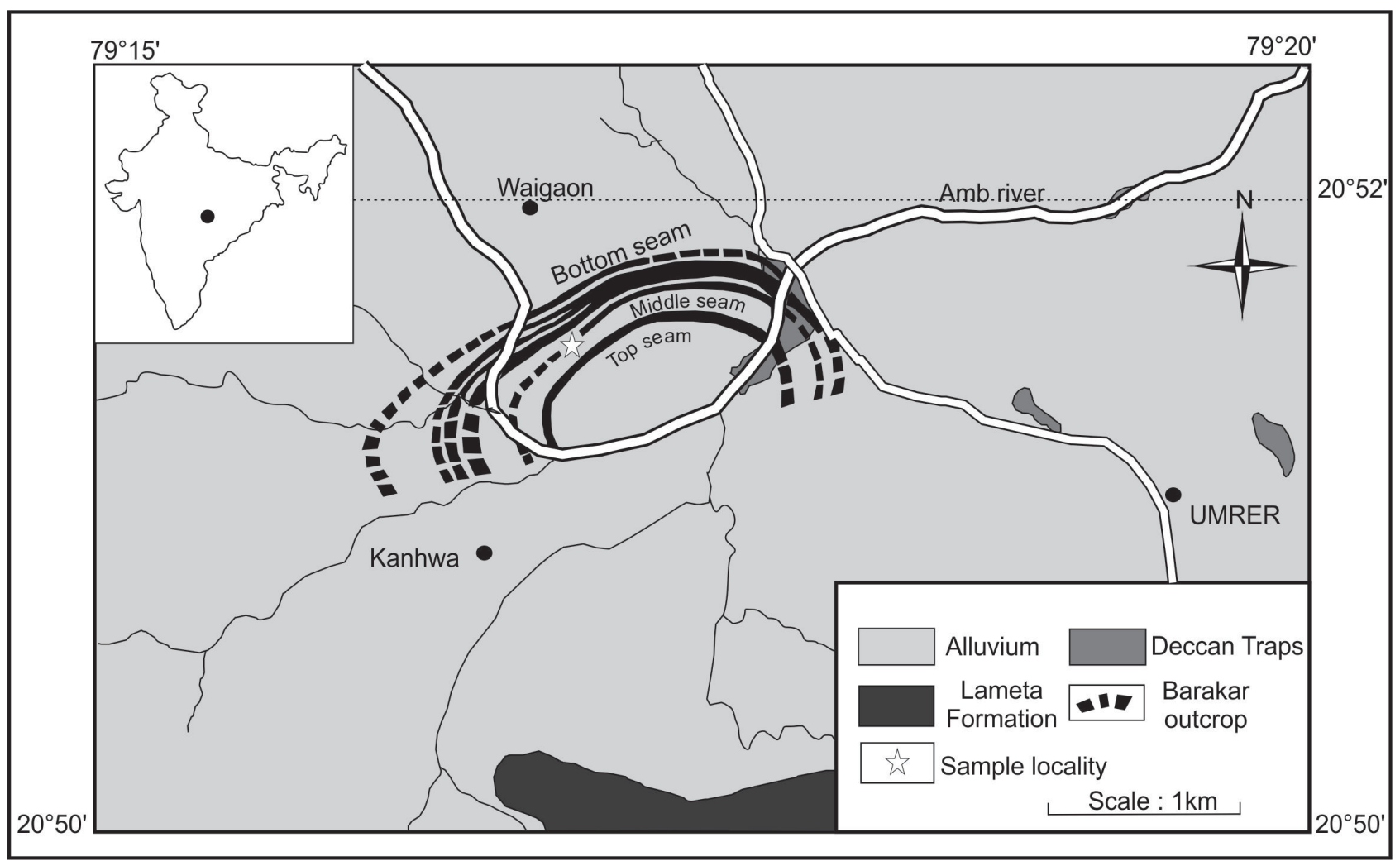

Figure 2. Geological Map of a part of the Umrer Coalfield showing the Coal Seams (after Raja Rao, 1982). 
Talchir Formation - the Archaean metamorphites are overlain by the Talchir Formation. The precise thickness of Talchir Formation has not been proved thus far due to the absence of surface exposures. They comprise of light green shales and fine grained sandstones.

Barakar Formation - overlies the Talchir Formation with a gradational contact. The total thickness of the Barakar Formation appears to be $200 \mathrm{~m}$ in the central part of the basin. The borehole data reveals that the Barakar sequence can be divided into three characteristic litho units- basal, middle and top members. The basal member is devoid of any workable coal seam and attains a maximum thickness of $72 \mathrm{~m}$. It is represented by fine to coarse grained greyish sandstone with interbands of grey and carbonaceous shales. The middle member of the Barakar Formation shows the development of all the coal seams and is characterised by an alternation of shales, sandstones and coal seams. This unit attains a thickness of $63 \mathrm{~m}$, the total thickness of the seam being $30 \mathrm{~m}$ to $35 \mathrm{~m}$. The top member is about $45 \mathrm{~m}$ thick and contains mainly coarse grained, medium to coarse grained sandstone with one prominent band of carbonaceous grey shale.

Kamthi Formation - the Kamthi's llithologies lie unconformable over the coal bearing Barakar beds. The formation is represented by ferruginous sandstones and shales. The sandstones display a reddish brown colour due to iron stains. Shales are light yellow to greenish in colour. Borehole data reveals a maximum thickness of $35 \mathrm{~m}$ of Kamthi Formation and it is quite possible that the top part of it might have been denuded. The formation is thickest in the axial part of the basin and thinner in the northeastern and southeastern parts.

Lameta Formation - the Kamthis are unconformable overlain by the Lametas and occur in isolated patches over the Gondwana sediments. The effect of pre-Kamthi and pre-Lameta erosions is well indicated from borehole data. As a result, the Kamthi and Lameta rocks show considerable variation in thickness, the Kamthi being present only in the western part. The Lameta Formation is almost absent in the western part of the coalfield but is developed in the rest of the area. It attains a greater thickness in the southeastern part of the coalfield. The maximum thickness of this formation is around $20 \mathrm{~m}$. It comprises primarily hard and compact calcareous sandstones and marly limestones.

Recent alluvium - the alluvium cover in the Umrer Coalfield area is represented by black cotton soil with montmorillonite rich clay, the thickness of the soil varies from $3 \mathrm{~m}$ to $14 \mathrm{~m}$.

\section{Description of coal seams}

According to Raja Rao (1982), in the Umrer Coalfield three coal seams designated as bottom, middle and top have been recognised ranging in thickness from $45 \mathrm{~m}$ to
$70 \mathrm{~m}$ (Figure 3). They are mainly confined to the Barakar Formation. The sequence of coal seams is given in Figure 4 and Table 2.

Bottom seam (Table 3): It is a composite stratum of seams I and II. It ranges in thickness from $15 \mathrm{~m}$ to $27 \mathrm{~m}$. In the southeastern part of the coalfield it attains a thickness of $16 \mathrm{~m}$ to $19 \mathrm{~m}$. The seam is split into five sections as A-E. These splits are well pronounced towards northwest and west. The parting between sections $\mathrm{E}$ and $\mathrm{D}$ is absent in the eastern half. The parting between sections $\mathrm{D}$ and $\mathrm{C}$ is absent in the north and the parting between sections $\mathrm{C}$ and $\mathrm{B}$ is absent in the southeastern part and the parting between sections $\mathrm{B}$ and $\mathrm{A}$ is absent in the south central part.

Table 1. Stratigraphic sequence of the Umrer Coalfield (after Raja Rao, 1982).

\begin{tabular}{|c|c|c|}
\hline Age & Formation & Lithology \\
\hline Recent & & Alluvium \\
\hline Cretaceous & Lameta & Limestones and Sandstones \\
\hline \multicolumn{3}{|c|}{ Unconformity } \\
\hline Early Triassic & Kamthi & $\begin{array}{l}\text { Reddish brown sandstones } \\
\text { yellow sandstones }\end{array}$ \\
\hline \multicolumn{3}{|c|}{ Unconformity } \\
\hline \multirow[t]{2}{*}{$\begin{array}{l}\text { Early } \\
\text { Permian }\end{array}$} & Barakar & $\begin{array}{l}\text { Coarse grained sandstones, } \\
\text { carbonaceous shales, coal seams }\end{array}$ \\
\hline & Talchir & $\begin{array}{l}\text { Greenish shales with occasional } \\
\text { bands of sandstones }\end{array}$ \\
\hline \multicolumn{3}{|c|}{ Unconformity } \\
\hline Archaean & Metamorphic & Schists and phylites \\
\hline
\end{tabular}

Table 2. Sequence of Coal seams in the Umrer Coalfield.

\begin{tabular}{lcc}
\hline \multicolumn{1}{c}{ Coal Seam } & Parting & $\begin{array}{c}\text { Thickness in } \\
\text { meter }\end{array}$ \\
\hline Top Seam & & $6.8-9.4$ \\
Middle Seam & Shale & $19-26$ \\
& & $3.4-6.4$ \\
Bottom Seam & Shale & $5-12$ \\
& & $15-27$ \\
\hline
\end{tabular}

Table 3. Sections A-E of Bottom seam.

\begin{tabular}{crl}
\hline $\begin{array}{c}\text { Section and } \\
\text { parting in } \\
\text { bottom seam }\end{array}$ & $\begin{array}{c}\text { Thickness in } \\
\text { meters }\end{array}$ & \multicolumn{1}{c}{ Remarks } \\
\hline Section E & $5.1-7.1$ & \\
Parting & $0-5.2$ & Absent in eastern half \\
Section D & $2.3-4.4$ & \\
Parting & $0-4.7$ & Absent locally in the north \\
Section C & $2.1-3.1$ & \\
Parting & $0-7.6$ & Absent in south eastern \\
& & part \\
Section B & $0.7-1.9$ & \\
Parting & $0-2.9$ & Absent in south central part \\
Section A & $2.0-4.0$ & \\
\hline
\end{tabular}




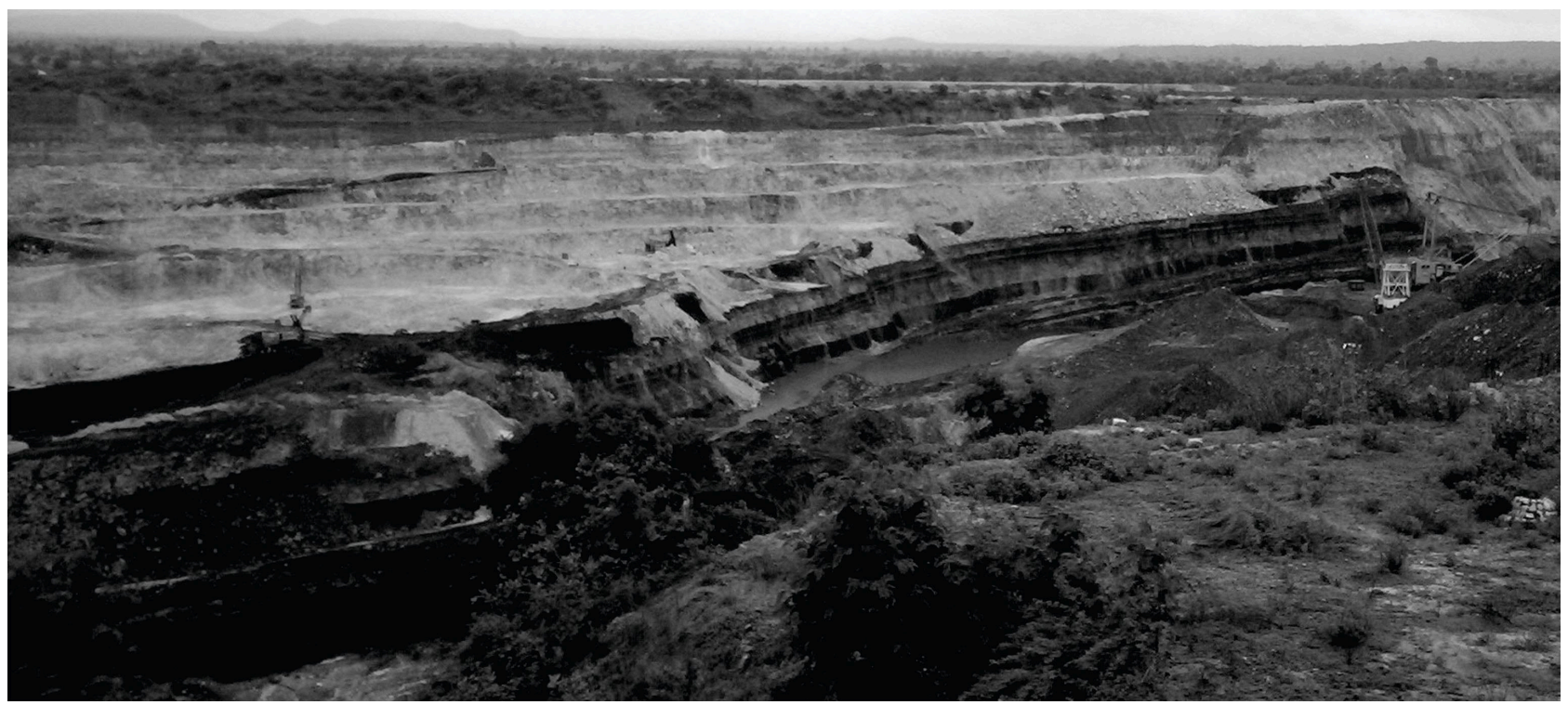

Figure 3. Field photo showing an overview of Bottom, Middle and Top seams with their partings.

Middle seam: It is also called as seam III. It varies in thickness from $3.5 \mathrm{~m}$ to $6.0 \mathrm{~m}$. The partings between the middle and the bottom seam increases gradually towards the west with the thinning of the middle seam in the same direction. One or two thin bands of shale with thickness of $0.45 \mathrm{~m}$ each can be observed in the middle.

Top seam: The middle seam is overlain by the top seam which is the fourth seam, with a parting of $20 \mathrm{~m}$ to $25 \mathrm{~m}$. The thickness of the seam varies from $6.5 \mathrm{~m}$ to $9.0 \mathrm{~m}$. It is an interbanded seam with 4-5 inconsistent dirt bands varying in thickness from $0.06 \mathrm{~m}$ to $0.5 \mathrm{~m}$. All the seams are mainly composed of coal, shaly-coal and thin bands of carbonaceous shale.

\section{PALYNOLOGICAL INVESTIGATIONS}

\section{Material and methods}

Fourteen samples (two samples from each seam and two samples from each parting) were macerated (Figure 4). In the Bottom seam only the samples from the parting between sections D and E could be collected as the partings from sections A to D were not accessible (Figure 4). The coal samples were devoid of spores and pollen but were rich in organic matter based on the analysis of which a paleoenvironmental interpretation was made (Pauline Sabina et al., 2010). Only the associated sediments were productive and the statistical analysis of the spores and pollen from these sediments constitutes the present study. The frequency distribution pattern of the genera in each of the samples is quantitatively characterized into dominant $(25 \%>)$, abundant (11-24\%), common (1-10\%), and rare (<1\%) (Vijaya, 1995).
Palynoassemblage is recognised following the criteria of dominance and sub-dominance of taxa (Vijaya, 1995; Jha et al., 2007). In addition, certain spores and pollen grains are considered qualitatively significant taxa.

The standard maceration technique has been adopted for the recovery of palynomorphs which involves nonchemical processes like cleaning and crushing of 5-10 gm of sample and chemical processes like demineralization, consisting of removal of carbonates by $10 \% \mathrm{HCl}$, removal of silicates by $40 \% \mathrm{HF}$, oxidation of organic matter with conc. $\mathrm{HNO}_{3}$ and removal of humic matter by $10 \% \mathrm{KOH}$. Sequel to chemical methods for release of microfossils some non-chemical techniques like sieving and swirling were used to achieve maximum concentration of palynomorphs. Later the macerates were mounted in Canada balsam and 4 slides per sample were prepared for observation. Stubs were also prepared from certain samples using the same residues, for examination in the scanning electron microscope. The sample material is deposited in the Department of Geology, University of Mysore, India, under the numbers MGG S1-MGG S14.

\section{Results}

Statistical analysis of the carbonaceous sediments have revealed the presence of 36 genera (sensu Bharadwaj, 1962; Bharadwaj and Salujha, 1964; Bharadwaj and Tiwari, 1964) which include 2 genera of Lycophytic spores- Indotriradites and Jayantisporites, 7 genera of Pteridophytic spores Leiotriletes, Horriditriletes, Lophotriletes, Brevitriletes, Microbaculispora, Microfoveolatispora and Callumispora. 27 gymnospermous pollen grains genera of which 7 are monosaccates-Divarisaccus, Caheniasaccites, Parasaccites, Striomonosaccites, Tuberisaccites, Crucisaccites 


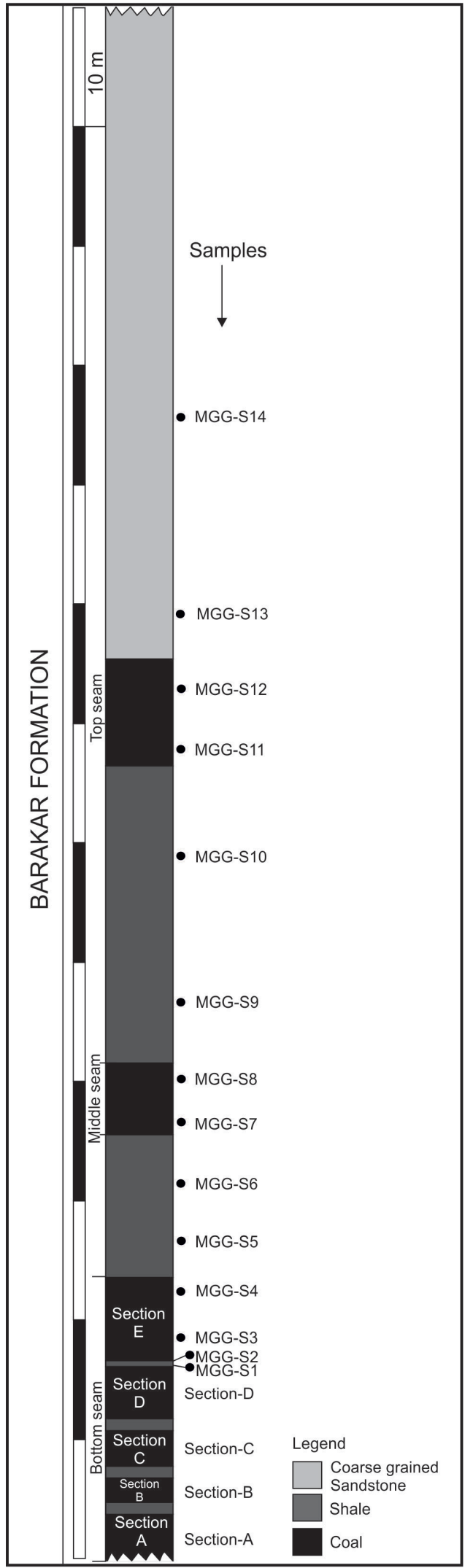

Figure 4. Lithology showing the sequence of coal seams in the Umrer Coal field. and Potonieisporites, 8 striate bisaccates- Striatites, Striatopodocarpites, Distriatites, Lahirites, Verticipollenites, Faunipollenites, Stroterosporites and Crescentipollenites, 2 taeniates -Lunatisporites and Lueckisporites and 10 non striate bisaccates - Vesicaspora, Rhizomaspora, Primuspollenites, Scheuringipollenites, Korbapollenites, Ibisporites, Platysaccus, Sahnites, Paravesicaspora and Cuneatisporites. The stratigraphically significant early Permian taxa are illustrated in Figure 5.

Miofloral composition of the shale parting between Sections D and E of Bottom seam (Figure 6)

Dominant taxa: Parasaccites (50\%)

Abundant taxa: Scheuringipollenites (14.25\%)

Common taxa: Divarisaccus (7\%), Virkkipollenites (9\%), Sahnites (4.5\%), Callumispora (4\%), Horriditriletes (3\%), Brevitriletes (3.5\%), Jayantisporites (2\%), Faunipollenites $(1 \%)$

Rare taxa- Leiotriletes (0.5\%), Microfoveolatispora $(0.5 \%)$, Striatites $(0.29 \%)$.

Miofloral composition of the shale between Bottom and Middle seam (Figure 7)

Dominant taxa: Parasaccites $(36.25 \%)$

Abundant taxa: Scheuringipollenites (18.5\%), Divarisaccus $(12.25 \%)$

Common taxa: Virkkipollenites (8\%), Faunipollenites (8\%), Callumispora (4\%), Striatites (2.5\%), Ginkgocycadophytus (2.5\%), Horriditriletes (2\%), Lophotriletes (1\%).

Miofloral composition of shale between Middle and Top seam (Figure 8)

Dominant taxa: Parasaccites (28\%)

Abundant taxa: Scheuringipollenites (14\%)

Common taxa: Horriditriletes (1.75\%), Brevitriletes (1.85\%), Callumispora (1.25\%), Tiwariasporis (2\%), Divarisaccus (2.25\%), Virkkipollenites (5\%), Crucisaccites (3.75\%), Lueckisporites (1.25\%), Striatites (3.75\%), Lahirites (1.75\%), Verticipollenites (2.75\%), Striatopodocarpites (1.2\%), Faunipollenites (1.25\%), Stroterosporites (1.5\%), Crescentipollenites (1.25\%), Vesicaspora (3.25\%), Rhizomaspora (1.75\%), Primuspollenites (5.5\%), Korbapollenites (2.25\%), Platysaccus (2.25\%), Cuneatisporites (1.25\%).

Rare taxa- Indotriradites $(0.75 \%)$, Jayantisporites (0.5\%), Lophotriletes (0.5\%), Ginkgocycadophytus (0.5\%), Leiosphaeridia (0.6\%), Plicatipollenites (0.5\%), Striomonosaccites $(0.5 \%)$, Tuberisaccites $(0.75 \%)$, Potonieisporites $(0.5 \%)$, Lunatisporites (0.75\%), Ibisporites (0.5\%), Paravesicaspora $(0.1 \%)$, Sahnites $(0.75 \%)$.

\section{PALYNOSTRATIGRAPHIC DATING AND CORRELATION}

Palynofossils are best suited for proposing biostratigraphic zonation of finer resolutions for the late Paleozoic sediments because of the production of spores and pollen 

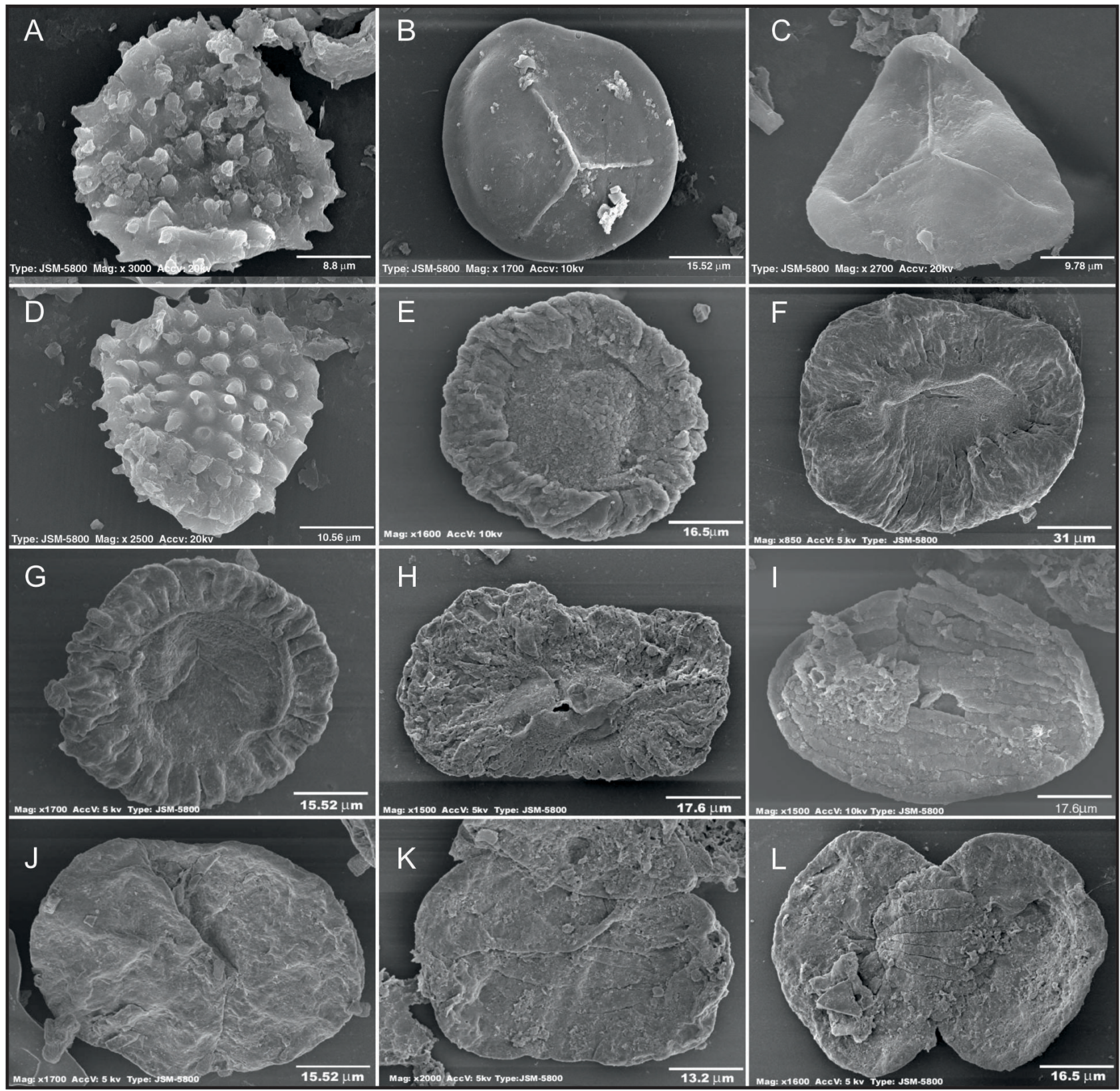

Figure 5. (A) Brevitriletes unicus Slide No.MGG-S11; (B) Callumispora barakarensis Slide No. MGG-S4; (C) Leiotriletes sphaerotriangulatus Slide No. MGG-S3; (D) Horriditriletes curvibaculosus Slide No. MGG-S7; (E) Parasaccites perfectus Slide No. MGG-S7; (F) Crucisaccites monoletus Slide No. MGG-S11; (G) Parasaccites perfectus Slide No. MGG-S11; (H) Caheniasaccites indicus Slide No. MGG-S7; (I) Tiwariasporis indicus Slide No. MGG-S8; (J) Scheuringipollenites maximus Slide No. MGG-S11; (K) Faunipollenites varius Slide No. MGG-S4; (L) Striatites rhombicus Slide No. MGG-S3.

in enormous numbers (by pteridophytes and gymnosperms) thus facilitating recovery of stratigraphically significant assemblages. Palynological studies have been extensively utilized in the biostratigraphic delineation of the Lower Gondwana sedimentary successions of India and several syntheses have been published during the last few decades (Bharadwaj, 1969, 1970, 1971, 1975) which has resulted in a clearer picture of the trend of vertical distribution of miofloras. The palynosuccession thus obtained has been used for dating and correlation of sediments.

In the recent years, for the precise and high resolution in palynostratigraphic delimitation of strata, the spore and pollen based zonation as given by Tiwari and Tripathi (1988) has been adopted in the Permian sequence of the Indian Peninsula. Accordingly, in India, the early Cisuralian Talchir Formation and the late Permian Raniganj Formation 


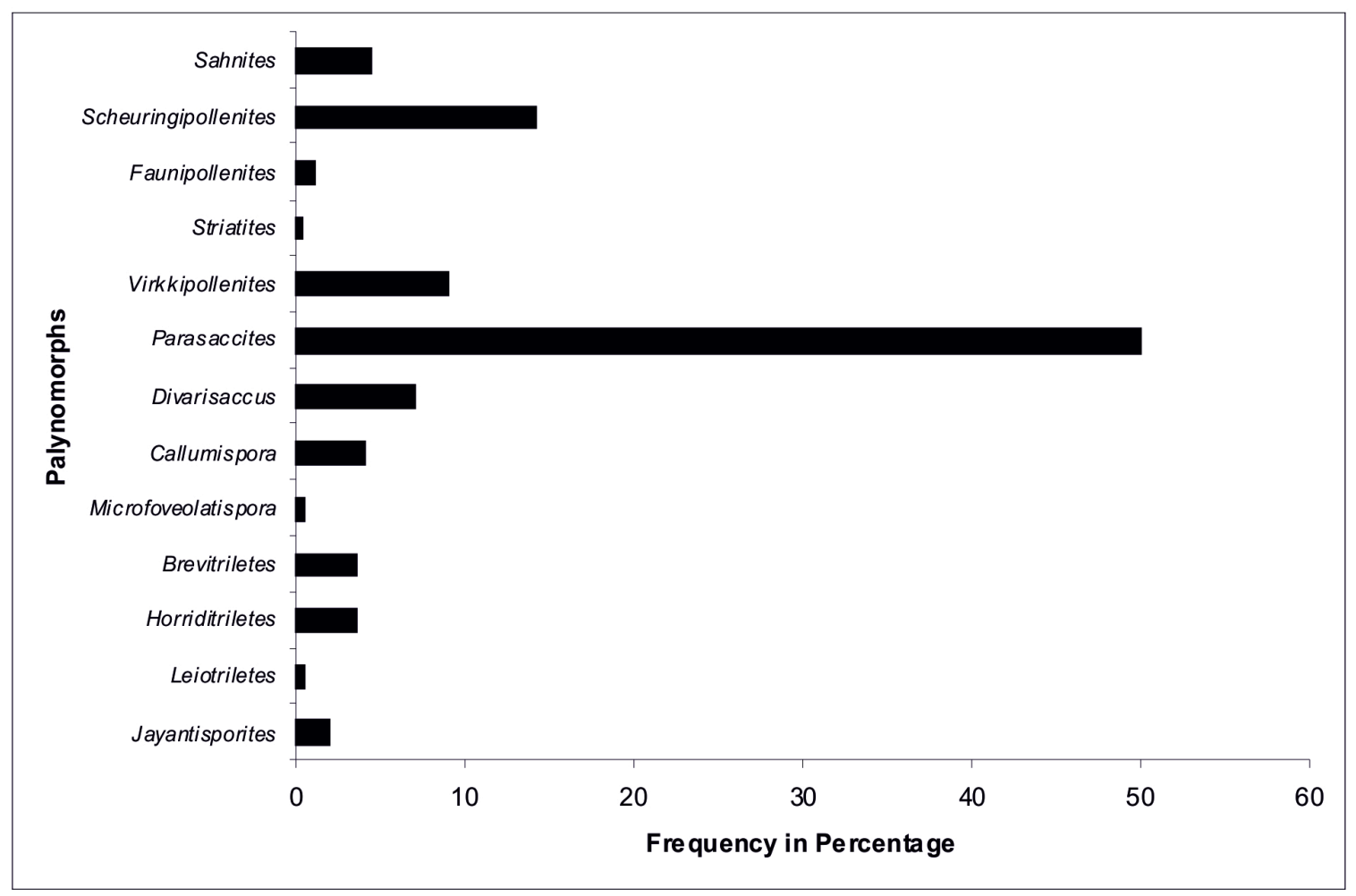

Figure 6. Histogram showing percentage frequency of palymomorphs in the shale parting between sections $D$ and $E$ of Bottom Seam.

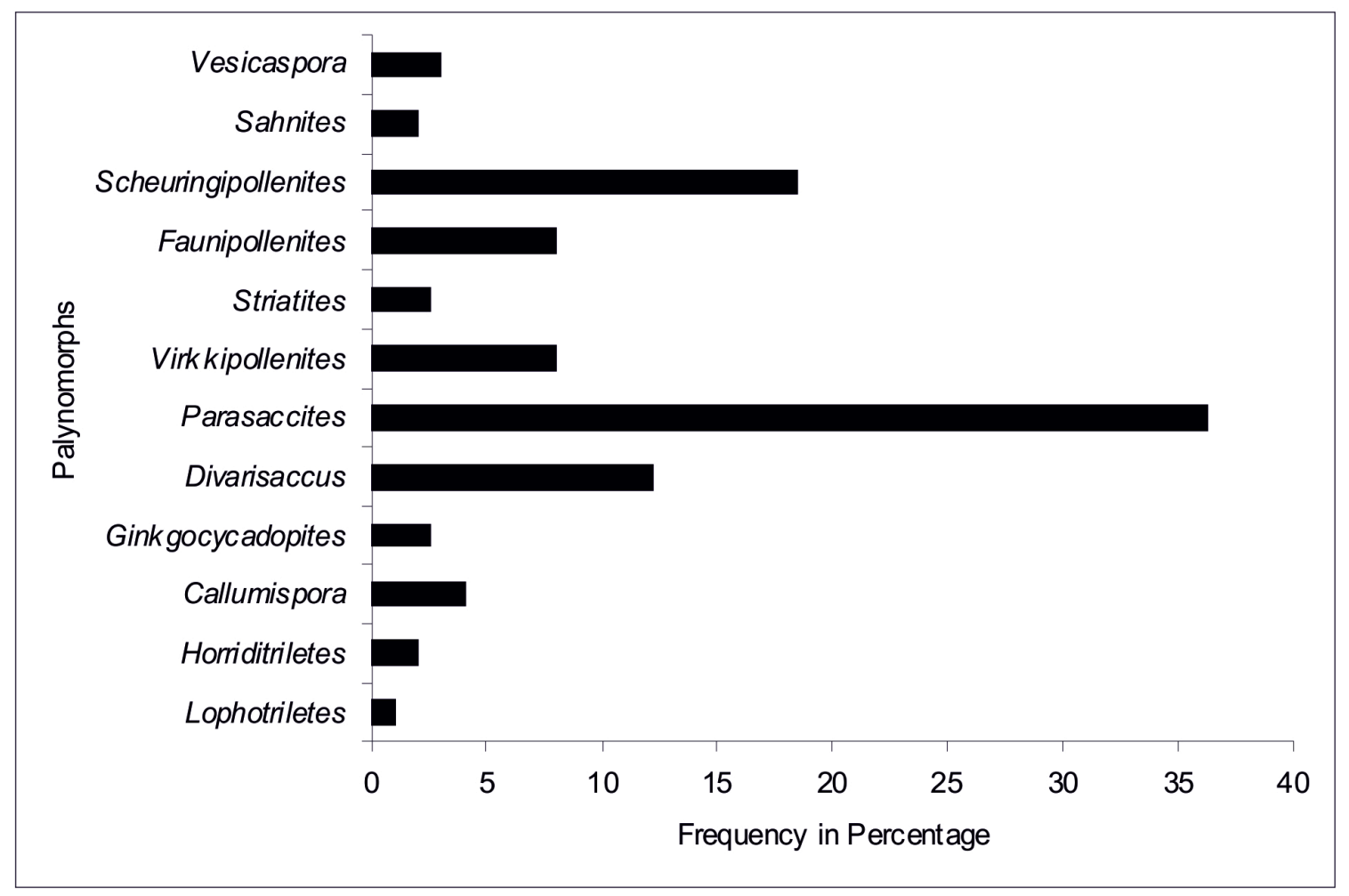

Figure 7. Histogram showing percentage frequency of palymomorphs in shale between Bottom Seam and Middle Seam. 


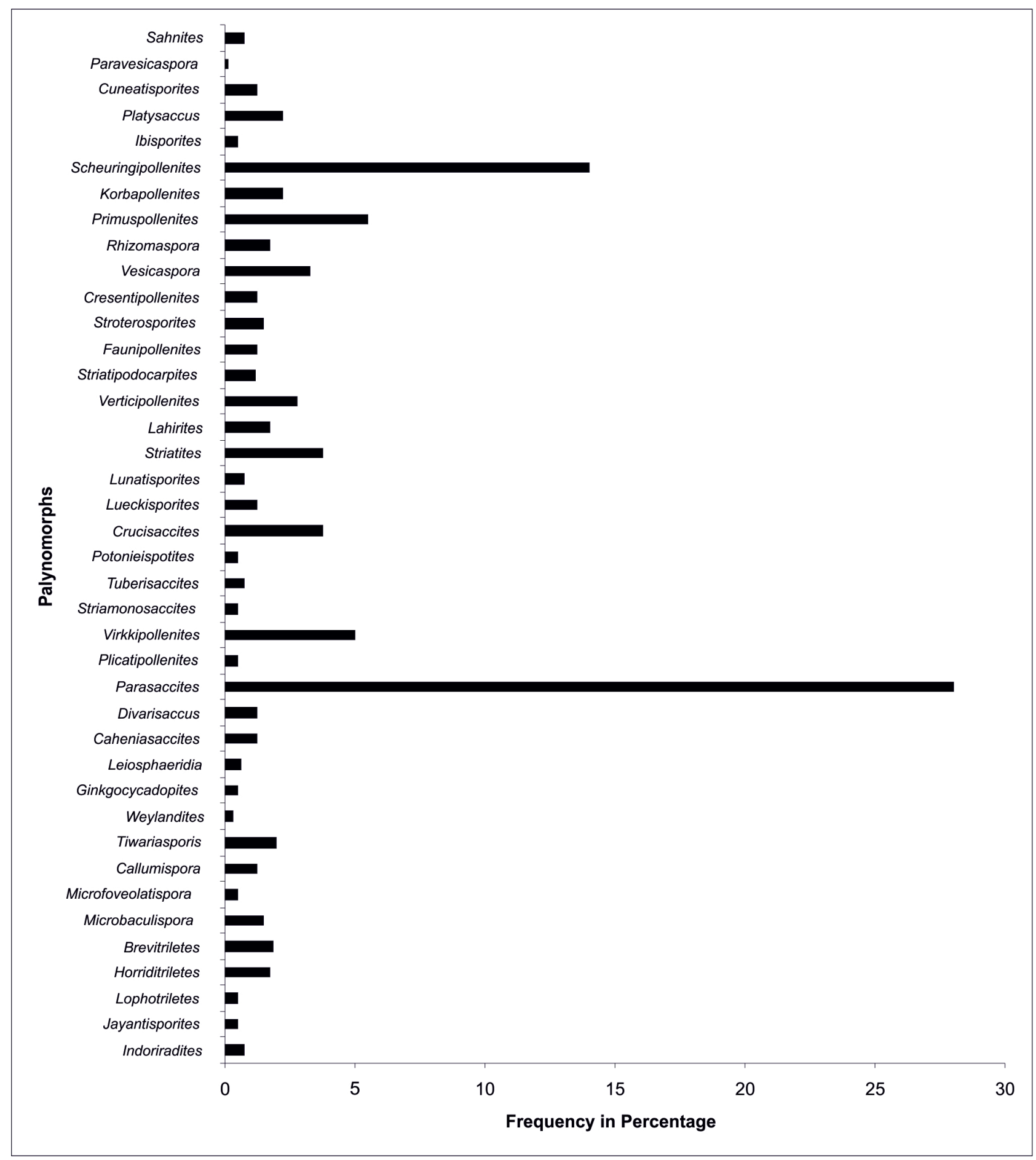

Figure 8. Histogram showing percentage frequency of palymomorphs in shale between Middle seam and Top Seam.

delimit the Permian sequence, including the coal strata in the Permian Period (ca 290-250 my). On the basis of the generic count through the Permian sequence, two major palynofloral phases have been recognised (Vijaya, 1995) viz. the older phase existed in the early Permian sequence i.e. in Talchir, Karharbari and Barakar formations, where the former two are characterized by the preponderance of radial monosaccate pollen grains in general and the latter is characterized by the abundance of non-striate bisaccate genus Scheuringipollenites. The younger phase prevailed 
during the late Permian i.e. in the Kulti (Barren Measures), and Raniganj formations having profound diversity of striate bisaccate pollen grains.

Srivastava (1992) has proposed the palynostratigraphic sequence in the Wardha-Godavari Basin wherein, the assemblage with the dominance of Callumispora and subdominance of Parasaccites characterizes with the lower Karharbari Formation while the assemblage the dominance of Parasaccites and subdominance of Scheuringipollenites characterizes the upper Karharbari Formation. These palynozones respectively represent the lower and upper Karharbari formations of other Gondwana basins of India. However, the Karharbari Formation is absent in the WardhaGodavari Basin as the Talchir sediments are conformably overlain by the Barakar sediments but palynological results of some borehole and outcrop samples have revealed the existence of palynozones equivalent to the Karharbari Formation in lithologically designated Barakar Formation.

The overall miofloristic pattern in the carbonaceous sediments of the bottom, middle and top seams of the Umrer coalfield reveal a radial monosaccate Parasaccites predominated and nonstriate bisaccate Scheuringipollenites subdominated sequence of deposition with slight fluctuations in the percentage frequency of occurrence of certain taxa at different stratigraphic levels (see Figures 6-8). The Parasaccites-Scheuringipollenites palynoassemblage (Srivastava, 1992) is comparable to the palynoassemblage of the upper Karharbari Formation from other Lower Gondwana basins. It is also authenticated by the presence of Crucisaccites monoletus corresponding to the Crucisaccites monoletus assemblage zone (IV) of Tiwari and Tripathi (1992) equivalent to the upper Karharbari Formation. The other significant taxa characteristic of the Karharbari Formation recorded from the study area are Callumispora, Caheniasaccites, Brevitriletes, Jayantisporites and Tiwariasporis. Therefore the palynoflora equivalent to the Karharbari Formation has been recognised in lithologically undifferentiated Barakar sequence. Evidently the three carbonaceous horizons are palynologically dated to belong to the early Permian age (late Sakmarian).

The Parasaccites-Scheuringipollenites palynoassemblage recorded from the Umrer Coalfield has been correlated with other coalfields within the Wardha-Godavari Basin and also with other Gondwana basins in India. Age deductions have also been made by correlation with equivalent assemblages within India, both intrabasinal and interbasinal correlation. It is further correlated with the early Permian palynoflora of other Gondwanan continents.

\section{India}

In the Wardha Basin, the Parasaccites-Scheuringipollenites palynoassemblage of the Umrer Coalfield from this study is comparable to that of Jha et al. (2007) from the Umrer
Coalfield. A comparative list of palynotaxa of the present study with that of Jha et al. (2007) is given in Table 4. It is comparable with the microflora of Assemblage A from Wardha Valley coalfield (Bhattacharrya, 1997), the assemblage from Kamthi Coalfield (Sarate, 1985), the palynoasssemblage I from the Ballarpur Colliery, Palynoassembalge I from the Durgapur colliery, Palynoassemblage I from borehole CMWNM 57 from barrier between Kawadi/Majri Open Cast Mine and Palynoassemblage I from Hindustan Lalpeth Colliery of Wardha Valley Coalfield (Jha et al., 2011).

In the Godavari Basin, the present assemblage can be correlated with the Palynozone 4 comprising assemblages of borehole GBR-2, 3 and 6) of Budharam area of Godavari Basin (Srivastava and Jha, 1995) and Assemblage 1 in bore core GGK-20 of Ramakrishnapuram and Ramagundam areas of Godavari Basin (Srivastava and Jha, 1989). Allthese assemblages are characterised by the dominance of Parasaccites and subdominance of Scheuringipollenites.

While with the other basins within India the Umrer assemblage is comparable with the Biozone- 2 of the Giridih Coalfield of Damodar Basin, the type locality for Karharbari Formation which is dominated by Parasaccites and subdominated by nonstriate bisaccates but the latter differs in having Limitisporites and Vesicaspora as the subdominant taxa (Srivastava, 1973). It closely compares with the palynoassemblages SC-I and SC-II of the lowermost workable Saharjuri coal horizon (Hait and Banerjee, 1994) and the palynoassemblage from North Karanpura Coalfield of Damodar Basin (Mukherjee and Ghosh, 1972) and Zone-2 of Pusai Shampur area, of Raniganj coalfield of Damodar Basin (Tiwari, 1973), Palynoassemblage from the Jharia coalfield of Damodar Basin (Tiwari et al., 1981) the microfloral zone-2 of Umaria Coalfield of South Rewa Basin (Srivastava and Anand-Prakash, 1984) and Zone-1 of Tatapani- Ramkola Coalfield of Koel-Damodar Basin (Kar and Srivastava, 2003) in having dominance of Parasaccites but all these differ from the former in having subdominance of Callumispora.

The Parasaccites-Scheuringipollenites palynoassemblage from the Umrer Coalfield is also comparable with the younger subzone of zone- 2 recorded by Bharadwaj and Srivastava (1973) from the Korba coalfield of Satpura Basin, Bagdona seam of Pathakera Coalfield of Satpura Basin (Sarate, 1986) in having dominance of Parasaccites and subdominance of Scheuringipollenites.

\section{Australia}

The eastern Australian palynostratigraphic scheme based on Evans (1967, 1969), Kemp et al. (1977) and Price (1983), is probably the most well-known of all the Gondwana palynostratigraphies. The early Permian has since then been divided by Foster and Waterhouse (1988) and Backhouse (1991, 1993). Backhouse divided the Permian sequence of the Collie, Perth and Officer Basins in Western Australia into a 
Table 4. A comparative palynotaxa list of Jha et al. (2007) with the present study (common taxa reported by both authors are shaded).

\begin{tabular}{|c|c|}
\hline Jha et al. (2007) & Present work \\
\hline Triletes & Triletes \\
\hline Leiotriletes sp. & Indotriradites korbaensis \\
\hline Lophotriletes rectus & Jayantisporites pseudozonatus \\
\hline Indotriradites sparsus & Leiotriletes magnificus \\
\hline I. korbaensis & Lophotriletes \\
\hline Jayantisporites pseudozonatus & Horriditriletes ramosus \\
\hline Horriditriletes rampurensis & H. novus \\
\hline H. ramosus & H. rajmahalensis \\
\hline Brevitriletes communis & H. bulbosus \\
\hline B. unicus & H. concavus \\
\hline Microbaculispora tentula & H. elegans \\
\hline M. barakarensis & H. curvibaculosus \\
\hline Microfoveolatispora foveolata & Horriditriletes sp. \\
\hline Calamospora exila & Lophotriletes rarus \\
\hline Callumispora barakarensis & Brevitriletes communis \\
\hline C. tenuis & Brevitriletes unicus \\
\hline Monosaccates & Microbaculispora gondwanensis \\
\hline Divarisaccus lelei & Microfoveolatispora foveolata \\
\hline Divarisaccus sp. & Callumispora gretensis \\
\hline Crucisaccites indicus & C. fungosa \\
\hline Caheniasaccites distinctus & C.barakarensis \\
\hline C. ovatus & Monosaccates \\
\hline C. ellipticus & Divarisaccus ovatus \\
\hline C. elongatus & D. Ielei \\
\hline Caheniasaccites sp. & Caheniasaccites indicus \\
\hline Parasaccites korbaensis & C. ellipticus \\
\hline P. obscurus & Parasaccites korbaensis \\
\hline P. diffusus & P. ovatus \\
\hline P. distinctus & P. perfectus \\
\hline Virkkipollenites orientalis & P. bilateralis \\
\hline Plicatipollenites indicus & P. obscurus \\
\hline Striate disaccates & Plicatipollenites densus \\
\hline Striatopodocarpites diffusus & Virkkipollenites orientalis \\
\hline S. decorus & V. triangularis \\
\hline Faunipollenites varius & Striomonosaccites sp. \\
\hline F. bharadwaji & Tuberisaccites varius \\
\hline F. parvus & Potonieispotites neglectus \\
\hline Non-Striate disaccates & Crucisaccites indicus \\
\hline Scheuringipollenites maximus & C. monoletus \\
\hline S. tentulus & Striate disaccates \\
\hline S. barakarensis & Striatites barakarensis \\
\hline Ibisporites jhingurdahiensis & S. medius \\
\hline Platysaccus sp. & S. rhombicus \\
\hline Others & S. communis \\
\hline Tiwariasporis gondwanensis & S. parvus \\
\hline \multirow[t]{5}{*}{ Ginkgocycadophytus sp. } & Lahirites rhombicus \\
\hline & L.reticuloidus \\
\hline & L. levicorpus \\
\hline & L. barakarensis \\
\hline & Verticipollenites secretus \\
\hline
\end{tabular}


Table 4. Continued...

\begin{tabular}{|c|c|}
\hline Jha et al. (2007) & Present work \\
\hline & V. gibbosus \\
\hline & V. oblongus \\
\hline & Striatipodocarpites cancellatus \\
\hline & S. ovalis \\
\hline & S. raniganjensis \\
\hline & S. diffusus \\
\hline & Faunipollenites singrauliensis \\
\hline & F. varius \\
\hline & Stroterosporites jansonii \\
\hline & Cresentipollenites gondwanensis \\
\hline & C. limpidus \\
\hline & C. fuscus \\
\hline & C. talchirensis \\
\hline & Non-striate disaccates \\
\hline & Vesicaspora ovata \\
\hline & Rhizomaspora indica \\
\hline & R. fimbriata \\
\hline & Primuspollenites brevicorpus \\
\hline & P. levis \\
\hline & P. singrauliensis \\
\hline & P. ovatus \\
\hline & Korbapollenites novus \\
\hline & Scheuringipollenites maximus \\
\hline & S. barakarensis \\
\hline & S. tentulus \\
\hline & Ibisporites diplosaccus \\
\hline & Platysaccus densicorpus \\
\hline & P. papillionis \\
\hline & P. brevizonatus \\
\hline & P. leschiki \\
\hline & P. ovatus \\
\hline & P. hingirensis \\
\hline & Cuneatisporites radialis \\
\hline & C. exiguus \\
\hline & Cuneatisporites sp. \\
\hline & Paravesicaspora ovatus \\
\hline & Sahnites thomasii \\
\hline & S. barrelis \\
\hline & S. congoensis \\
\hline & Taeniates \\
\hline & Lueckisporites sp. \\
\hline & Lunatisporites rhombicus \\
\hline & Lunatisporites sp. \\
\hline & Others \\
\hline & Tiwariasporis indicus \\
\hline & Ginkgocycadophytus novus \\
\hline & Weylandites multistriatus \\
\hline & Leiosphaeridia talchirensis \\
\hline
\end{tabular}


number of mainly internal zones, partly based on the eastern Australian Stage nomenclature. In ascending order these are: Stage 2 (sensu Backhouse, 1991), Pseudoreticulatispora confluens zone, Pseudoreticulatispora pseudoreticulata zone, Striatopodocarpites fusus zone, Microbaculispora trisinia zone and Praecolpatites sinuosus zone.

The Pseudoreticulatispora confluens Oppel zone is characterised by key taxa: Pseudoreticulatispora confluens, Brevitriletes cornutus, Brevitriletes levis, Densoisporites rotundidentatus, Horriditriletes ramosus, Jayantisporites pseudozonatus, Converrucosisporites grandegranulatus, Microbaculispora tentula, Pachytriletes densus, callumispora gretensis, Parasaccites sp., Caheniasaccites ovatus, Cycadopites cymbatus, Limitisporites rectus, Marsupipollenites striatus, Plicatipollenites sp., Protohaploxypinus limpidus, Striatoabieitites multistriatus and Stellapollenites sp. According to Foster and Waterhouse (1988) not all the taxa appear in every assemblage, but an association of at least four of the key taxa, together with Pseudoreticulatispora confluens allows recognition of the zone.

The Umrer assemblage allows recognition of most of the taxa mentioned above but with the absence of Pseudoreticulatispora confluens, this suggests a correlation of the Umrer assemblage with palynofloras younger than the Pseudoreticulatispora confluens zone. However, qualitatively the Umrer assemblage is comparable with the Pseudoreticulatispora confluens zone.

Stage 3b (Backhouse, 1991) is characterised by striate bisaccates being more common and monosaccate pollen are less abundant, the Umrer assemblage therefore differs quantitatively in having dominance of monosaccates and subdominance of nonstriate bisaccates. But, qualitatively the Umrer assemblage is comparable with the Stage $3 b$ identified in the Reids Dome beds of the Bowen Basin, eastern Australia (Rigby and Hekel, 1977), the Upper part of the Stuart range Formation and Mount Toondina Formation in the Arckaringa Basin, South Australia (Gilby and Foster, 1988) and in Tasmania (Truswell, 1978; Calver et al., 1984).

\section{Antarctica}

The oldest early Permian assemblages are found in the Darwin Tillite, South Victoria Land (Kyle, 1977), and in the equivalent rocks in the Ohio and Wisconsin Ranges and the Nilsen Plateau in the Transantarctic Mountains (Kyle and Schopf, 1982), which belongs to the Parasaccites zone, originally designated by Kyle (1977). This zone is characterised by the abundance of monosaccate pollen grains predominantly Parasaccites and is therefore comparable with the palynoassemblage from the Umrer coalfield which shows predominance of Parasaccites but the Umrer assemblage differs from the Parasaccites zone of Kyle (1977) in having subdominance of bisaccate pollen grains which are rare in the Parasaccites zone. The trilete spores like Punctatisporites sp. (Callumispora sp.), Leiotriletes sp., Microbaculispora and pollen assignable to Cycadopites are common to abundant in the Parasaccites zone which is also recorded in the assemblage from the Umrer Coalfield. Qualitatively, the Parasaccites - Scheuringipollenites zone suggests its correlation with the Protohaploxypinus zone designated by Kyle (1977), recognised in the upper part of member $\mathrm{A}$ and ranges through member $\mathrm{B}$ and $\mathrm{C}$ of the Weller Coal Measures.

The assemblages from locality A in Milorgfjella and Lidkvarvet in Sivorgfjella, Droning Maud Land (Lindstrom, 1995) contain many typical early Permian Gondwana taxa such as Lycopod spores Jayantisporites pseudozonatus, Pterophyte spores Leiotriletes sp., Horriditriletes sp., Callumispora gretensis, Gymnospermous grains Parasaccites sp., Plicatipollenites, Scheuringipollenites sp., Faunipollenites sp. and Sahnites and Leiosphaeridia, which have also been recorded in the Umrer coalfield and is therefore possibly comparable. However, the assemblage from the Umrer Coalfield differs from the Locality A and Lidkvarvet in the absence of Pseudoreticulatispora confluens, Didecitriletes, Vittatina sp. and Barakarites. It is also comparable with the early Permian palynoflora from Milorgfjella, Droning Maud Land (Larsson et al., 1990), in having predominance of Cannanoropollis sp. but differs in having lesser percentage of Plicatipollenites and triletes and also in the absence of Praecolpate pollen grains Marsupipollenites striatus and apiculate spores Granulatisporites sp.

\section{Africa}

Palynological studies of the Karoo Supergroup (Dwyka and Ecca groups) in South Africa have been undertaken by various workers in several of the contemporaneous Karoo basins of southwestern Gondwana (e.g. Falcon, 1975; Anderson, 1977; MacRae, 1988; Millsteed, 1999). Anderson (1977) carried out a comprehensive palynological study of African Permian strata on the northern Karoo Basin in South Africa. Recently, Jha (2006) summarised various palynological zonations within the African Gondwana Basins. In general the Umrer palynoflora can be correlated with the Mukumba assemblage from Luwumbu Coal Formation (lower Karoo) in the northern part of the Luangwa valley, Zambia (Utting, 1976) which is dominated by monosaccate palynomorphs like Parasaccites and qualitatively by the presence of Leiotriletes sp., Callumispora gretensis, Zinjisporites (= Jayantisporites) sp. and Vesicaspora . The Mpwashi assemblage of Luwumbu coal Formation (lower Karoo) in the northern part of the Luangwa valley, Zambia (Utting, 1976) is characterised by the presence of bisaccates like Vesicaspora, Faunipollenites, Striatopodocarpites, Striatites, trilete genera like Leiotriletes, Horridtriletes and monosaccates like Parasaccites, Plicatipollenites and Striomonosaccites in varying percentages which are also recorded in the Umrer 
coalfield and therefore can be qualitatively correlated with the palynoflora of the Umrer coalfield. However the palynomorphs Hamiapollenites, Vittatina africana and Vittatina saccata, Retusotriletes, Cirratriradites and Granulatisporites of the Mpwashi assemblage are absent in the Umrer assemblage. Qualitatively, the Umrer assemblage is also comparable with the lower Coal measures (K2) from the Ketewaka/Mchuchuma and Songea coalfields, Tanzania (Hart, 1960, 1963, 1965) in which the presence of Zingisporites, Faunipollenites, Vesicaspora, Parasaccites and Plicatipollenites has been reported. It can be correlated with the Scheuringipollenites assemblage zone from the lower part of the Mchuchuma Formation (Semkiwa et al., 1998, 2003) Tanzania on the basis of the presence of Parasaccites, Caheniasaccites, Scheuringipollenites and trilete spores. It closely corresponds to the upper part of KKI biozone of Kobe Formation (lower Ecca Group), Modie and Le Hérissé (2009) from the Kalahari Karoo Basin, Botswana, as they also share in common the above palynoflora.

\section{South America}

In the Gondwanan continent among the farthest lands, from each other were Paraná Basin and Indian Gondwanan basins separated by, at least, $3000 \mathrm{~km}$ of African continuous lands. Although, considering that the continents were covered only by gymnosperms and pteridophyte plants, whose reproductive elements were dispersed preferentially by the wind, it is possible to suggest some palynological biostratigraphical correlation between them.

A review of the Carboniferous - Permian palynology of South America was carried out by Azcuy (1979). Several Late Paleozoic palynozonation schemes were established for the Parana Basin of South America, one of the oldest being the one proposed by Daemon and Quadros (1970) in the Tubarão and Passa Dois groups. Later, Marques-Toigo $(1988,1991)$ renamed the interval zones of Daemon and Quadros (1970). This was followed by a reinterpretation of the palynostratigraphy of the Parana Basin by Souza and Marques-Toigo (2003) and Souza (2006). According to them, the Gondwana I sequence of the Parana Basin was characterised by four interval zones namely 1) Ahrensisporites cristatus (AcZ); 2) Crucisaccites monoletus (CmZ), both included in Pennsylvanian; 3) Vittatina costabilis (VcZ) with two Subzones: Protohaploxypinus goraiensis and Hamiapollenites karrooensis and 4) Lueckisporites virkkiae (LvZ) for the early to early middle Permian. The Vittatina costabilis Interval Zone (VcZ) was before named Cannanoropolis korbaensis Interval Zone while the Protohaploxypinus goraiensis Subzone was divided in Protohaploxypinus goraiensis Subzone and Caheniasaccites ovatus Subzone after Marques-Toigo $(1988,1991)$.

The Ahrensisporites cristatus (AcZ) is recognised in the basal portion of the Itarare Subgroup and is assigned a Pennsylvanian (late Bashkirian to Kasimovian) age, this is overlain by the Crucisaccites monoletus $(\mathrm{CmZ})$ which ranges from the top of the lower portion to the middle portion of the Itarare Subgroup and is assigned a Late Pennsylvanian (Kasimovian to Gzhelian) age. Both these zones are characterised by the dominance of trilete spores and monosaccate pollen grains with a few taeniate pollen grains but the first appearance of Crucisaccites monoletus and Scheuringipollenites maximus in the Crucisaccites monoletus (CmZ) distinguishes itself from the Ahrensisporites cristatus (AcZ). Above this, is the basal Protohaploxypinus goraiensis Subzone of the Vittatina costabilis Interval Zone recognised for the first time in the upper portion of the Itararé Subgroup in the northeastern Paraná Basin. This zone is characterised by the dominance of monosaccate pollen grains along with taeniate grains and is attributed to the early Permian (early Cisuralian).

The palynoasemblage from the Umrer Coalfield which is characterised by the dominance of monosaccate pollen grains and the presence of Crucisaccites monoletus and Scheuringipollenites maximus suggests a possible correlation with the middle upper part of the Itararé Group (Crucisaccites monoletus interval zone) to the basal portion of Protohaploxypinus goraiensis subzone. This further suggests that the Gondwana floral succession is older in Brazil with migration to India during the Sakmarian-Artinskian, as within the Paraná Basin of Brazil, the Crucisaccites monoletus Zone is typical of Itararé Sub-group (top of the lower portion to the middle) corresponding to Upper Carboniferous, Kasimovian to Gzhelian while in India it corresponds to the early Permian Sakmarian-Artinskian (Jha et al., 2012).

In Uruguay, it is comparable with the Cristatisporites inconstans-Vittatina saccata Assemblage Zone (IS) identified in the San Gregorio and Tres Islas Formations and in the basal part of the Melo Formation (Fraile Muerto Member) which is characterised by trilete spores and monosaccate pollen and, to a lesser extent, by non-taeniate bisaccate, taeniate bisaccate and plicate pollen grains (Beri et al., 2011). An early Cisuralian age is proposed for this Zone.

Correlation of the Indian and Argentinian biozones is difficult; but Césari and Gutiérrez (2000) proposed that the Scheuringipollenites barakarensis Assemblage Zone (V) of Tiwari and Tripathi (1992) is equivalent with the Argentinian Lueckisporites-Weylandites (LW) Assemblage Biozone using the first appearance of Weylandites. The co-occurrence of Parasaccites, Caheniasaccites, Lueckisporites, Brevitriletes in the LW Biozone and the Umrer assemblage suggests correlation of the two. Recent studies on Argentinan Permian assemblages from Río Francia (Gutiérrez et al., 2010), La Veteada (Gutiérrez et al., 2011) and Andapaico formations (Correa et al., 2012; Balarino et al., 2012) have incorporated new elements to LW Biozone, some of which are in common with the Umrer assemblage (e.g. Caheniasaccites flavatus, 
Potonieisporites lelei, Scheuringipollenites maximus, Illinites unicus) thus favouring their correlation.

It is also comparable with the lower member and coal member of the Copacabana Formation from Apillapampa, Central Bolivia on the basis of common occurrence of species of Parasaccites, Scheuringipollenites, Potonieisporites, Plicatipollenites, Lueckisporites, Illinites, Horriditriletes and Brevitriletes (di Pasquo and Grader, 2012; di Pasquo et al., 2014).

\section{CONCLUSION}

The early Permian sediments are characterized by glacial deposits at its base and palynological assemblages associated with the glacial deposits are characterized by the abundance of monosaccate pollen and the immediate post glacial deposits are characterised by the appearance and dominance of non-striate bisaccate pollen grains followed by relative abundance of striate bisaccates (Schopf and Askin, 1980). Similar palynological assemblage pattern can be observed in the early Permian sediments throughout the southern land masses. The palynomorph assemblage found in the samples from the Umrer Coalfield contain preponderance of the radial monosaccate genus Parasaccites with subdominance of non-striate bisaccate genus Scheuringipollenites in association with many early Permian taxa such as Crucisaccites Callumispora, Caheniasaccites, Tiwariasporis, Plicatipollenites, Microbaculispora, Horriditriletes, Brevitriletes, Leiotriletes, Jayantisporites. Evidently the Umrer Coalfield palynologically corresponds to the Parasaccites-Scheuringipollenites Zone of Godavari Basin (Srivastava, 1992) which is typical of the early Permian upper Karharbari Formation, Sakmarian to Artinskian age. Age deductions have been drawn by correlations with similar assemblages from different basins in India and also with the early Permian palynoflora from other Gondwanan continents. Some of these assemblages have been associated with sediments which have been radiomertically dated, especially the assemblages from South America (Césari, 2007; Stollhofen et al., 2000; Santos et al., 2006; Gulbranson et al., 2010) and Africa (Bangert et al., 1999) which suggest an age not younger than early Artinskian. These correlations enabled to equate the Indian Upper Karharbari Formation to their global counterparts, the Ewington Member of Collie Basin Australia, Weller Coal Measures (upper part of Member A and Member B) of South Victoria Land, Antarctica, Ecca Group (Mchuchuma Formation and Kobe Formation) of Karoo Basin, Africa, in the Paraná Basin the upper part of the Itararé Group and the Rio Bonito Formation of Brazil, San Gregorio and Tres Islas formations and in the basal part of the Melo Formation (Fraile Muerto Member) of Uruguay and basal parts of Río Francia, La Veteada and Andapaico formations of Argentina and also the lower member and coal member of the Copacabana Formation from Apillapampa, Central Bolivia of South America.

\section{ACKNOWLEDGEMENTS}

The author PSK is grateful to Director Birbal Sahni Institute of Paleosciences, Lucknow for granting permission to come to Brazil. The authors thank the Conselho Nacional de Desenvolvimento Científico e Tecnológico (CNPq) for finance support to M.E.C. Bernardes-de-Oliveira (401147/2014-2), PSK (300578/2015-6) and MS (150574/2015-0). The authors are also grateful to Prof. Srikantappa the Ex. Chairman of the Department of studies in Geology and Dr. H.T. Basavarajappa Chairman of the Department of studies in Geology University of Mysore for providing facilities to carry out the Ph.D. work. We are also grateful to the Deputy General Manager of Umrer Coalfield, Western Coalfields Limited for granting permission to carry out field work and collection of samples. The authors thank the reviewers Rodolfo Dino and Diana R. Boardman for their helpful suggestions which improved the text.

\section{REFERENCES}

Acharyya, S. K. (2000). Coal and lignite resources of India: an overview, 50. Bangalore: Publications of the Geological Society of India.

Agashe, S. N. (1979). Megaspores from the Permian coal seams (lower Gondwana) of Umrer Colliery, Nagpur District, Maharashtra, India. Proceedings of the IV International palynological Conference, v. 2, 627-634. Lucknow: Birbal Sahni Institute of Palaeobotany.

Agashe, S. N., Chitnis, S. R. (1970). Palynological investigation of coalseams of Lower Gondwana strata from Maharashtra, India-A preliminary report. Palynological Bulletin, VI(1), 6-8.

Agashe, S. N., Chitnis, S. R. (1972). Palaeopalynology of a Permian coal seam from the Hindustan Lalpeth Colliery, Chandrapur district, Maharashtra, India. Seminar on Palaeopalynology and Indian Stratigraphy, 21-29.

Anderson, J. M. (1977). The biostratigraphy of the Permian and Triassic: part 3: a review of Gondwana palynology with particular reference to the northern Karoo Basin. Memoirs of the Botanical Survey of South Africa, 41, 1-188.

Azcuy, C. L. (1979). A review of the early Gondwana palynology of Argentina and South America. Proceedings of the IV International Palynological Conference, v. 2, 175-185. Lucknow. 
Backhouse, J. (1991). Permian palynostratigraphy of the Collie Basin, Western Australia. Review of Palaeobotany and Palynology, 67, 237-314.

Backhouse, J. (1993). Palynology and correlation of Permian sediments in the Perth Collie, and Officer Basins, Western Australia. Geological Survey of Western Australia Reports, 34, 111-128.

Balarino, M. L., Correa, G. A., Gutiérrez, P. R., Carrevedo, M. L. (2012). Palinología de la Formacíon Andapaico (Cisuraliano-Guadalupiano), Precordillera Central Sanjuanina, Argentina: consideraciones bioestratigráficas regionales. Revista Brasileira de Paleontologia, 15, 281-299.

Bangert, B., Stollhofen, H., Lorenz, V., Armstrong, R. (1999). The geochronology and significance of ash-fall tuffs in the glaciogenic Carboniferous-Permian Dwyka Group of Namibia and South Africa. Journal of South American Earth Sciences, 29, 33-49.

Beri, A., Gutiérrez, P., Balarino, L. (2011). Palynostratigraphy of the late Palaeozoic of Uruguay, Paraná Basin. Review of Palaeobotany and Palynology, 167, 16-29.

Bharadwaj, D. C. (1962). The miospore genera in the coals of Raniganj Stage (Upper Permian), India. The Palaeobotanist, 9, 68-106.

Bharadwaj, D. C. (1969). Lower Gondwana formations. $\mathrm{Cr}$. 6th International Congress on Carboniferous Geology and Stratigraphy, 1, 255-278. Sheffield.

Bharadwaj, D. C. (1970). Palynological subdivisions of the Gondwana sequence in India. Proceedings of the II International Gondwana Symposium, 531-536. Pretoria.

Bharadwaj, D. C. (1971). Palynostratigraphy of lower Gondwana successions in India. International Gondwana Symposium, Annals of Geology Department, v. 5-6, 30-419. Aligarh: Aligarh Muslim University.

Bharadwaj, D. C. (1975). Palynology in biostratigraphy and palaeoecology of Indian lower Gondwana Formations. The Palaeobotanist, 22, 150-157.

Bharadwaj, D. C., Anand-Prakash. (1974). Palynostratigraphy of lower Gondwana sediments from Umrer Quarry, Nagpur, Maharashtra, India. Geophytology, 4(2), 130-140.

Bharadwaj, D. C., Salujha, S. K. (1964). Sporological study of Seam VIII in Raniganj Coalfield, Bihar (India), part I: description of sporae dispersae. The Palaeobotanist, 12(2), 181-215.

Bharadwaj, D. C., Srivastava, S. C. (1973). Subsurface palynological succession in Korba Coalfield, Madhya Pradesh, India. The Palaeobotanist, 20(2), 137-151.
Bharadwaj, D. C., Tiwari, R. S. (1964). On two monosacate genera from Barakar Stage of India. The Palaeobotanist, 12(2), 139-146.

Bhattacharrya, A. P. (1997). Palynological recognition of the Karharbari-Barakar Formationsin the sub-surface sediments of Wardha Coalfield, Maharashtra, India. The Palaeobotanist, 46(1,2), 217-219.

Calver, C. R., Clarke, M. J., Truswell, E. M. (1984). The Stratigraphy of a Late Palaeozoic borehole section at Douglas river, eastern Tasmania: a synthesis of marine macroinvertebrate and palynological data. Paper Proceedings of the Royal Society of Tasmania, 188, 137-161.

Césari, S. N. (2007). Palynological biozones and radiometric data at the Carboniferous-Permian boundary in Western Gondwana. Gondwana Research, 11, 529-536.

Césari, S. N., Gutiérrez, P. R. (2000). Palynostratigraphy of Upper Paleozoic Sequences from Central-Western Argentina. Palynology, 24, 113-146.

Correa, G. A., Carrevedo, M. L., Gutiérrez, P. R. (2012). Paleoambiente y paleontologia de la Formación Andapaico (Paleozoico superior, Precordillera Central, Argentina). Andean Geology, 39, 22-52.

Daemon, R. F., Quadros, L. P. (1970). Bioestratigrafia do Neopalezoico da Bacia do Paraná. Anais do XXIV Congresso Brasileiro de Geologia, 359-412. Brasilia.

di Pasquo, M., Grader, G. W. (2012). Palynology and paleoenvironment of the Asselian-? Artinskian Copacabana Formation at Apillapampa near Cochabamba, Bolivia. Palynology, 36, 264-276.

di Pasquo, M., Grader, G. W., Isaacson, P., Souza, P. A., Iannuzzi, R., Díaz-Martínez, E. (2014). Global biostratigraphic comparison and correlation of an early Cisuralian palynoflora from Bolivia. Historical Biology, 27(7), 868-897.

Evans, P. R. (1967). Upper Caboniferous and Permian palynological stages and their distribution in eastern Australia. Australian Bureau of Mineral Resources Records, 1967-1999.

Evans, P. R. (1969). Upper Caboniferous and Permian palynological stages and their distribution in eastern Australia. Gondwana Stratigraphy International Union of Geological Sciences Symposium, 2, 41-54. Argentina: UNESCO.

Falcon, R. M. S. (1975). Palynostratigraphy of the lower Karroo sequence in Sebungwe District, Mid Zambezi Basin, Rhodesia. Paleontographica Abt.B, 18, 1-29.

Foster, C. B., Waterhouse, J. B. (1988). The Granulatisporites confluens Oppel-zone and Early Permian marine faunas from the Grant Formation on the Barbwire Terrace, canning Basin, Western Australia. Australian Journal of Earth Sciences, 35, 135-157. 
Gilby, A. R., Foster, C. B. (1988). Early Permian palynology of the Arckaringa Basin, South Australia. Palaeontographica Abt.B, 209, 167-191.

Gulbranson, E. L., Montañez, I. P., Schmitz, M. D., Limarino, C. O., Isbell, J. L., Marenssi, S. A., Crowley, J. L. (2010). High-precision $\mathrm{U}-\mathrm{Pb}$ calibration of Carboniferous glaciation and climate history, Paganzo Group, NW Argentina. Geological Society of America Bulletin, 122, 1480-1498.

Gutiérrez, P. R., Correa, G. A., Carrevedo, M. L. (2010). Primer registro de palinomorfos de edad pérmica en la Formación Río Francia (Paleozoico Superior, San Juan, Argentina). Revista del Museo Argentino de Ciencias Naturales, 12, 203-216.

Gutiérrez, P. R., Zavattieri, A. M., Ezpeleta, M., Astini, R. A. (2011). Palynology of the La Veteada Formation (Permian) at the Sierra de Narvaéz, Catamarca Province, Argentina. Ameghiniana, 48, 154-176.

Hait, A. K., Banerjee, M. (1994). Palynofloristic study of Permian sediments from Saharjuri Basin, Bihar, with remarks on age. Journal of the Palaeontological Society of India, 39, 13-28.

Hart, G. F. (1960). Microfloral investigations of the lower Coal Measures (K2): Ketewaka-Mchuchuma Coalfield, Tanganyika. Bulletin Geological Survey of Tanganyika, 30, 1-18.

Hart, G. F. (1963). Microflora from the Ketewaka Mchuchuma Coalfield, Tanganyika. Bulletin Geological Survey of Tanganyika, 36, 1-27.

Hart, G. F. (1965). Miospore zones in Karoo sediments of Tanzania. Paleontologia Afric, 9, 139-150.

Jha, N. (2006). Permian Palynology from India and Africa: a Phytogeographical paradigm. Journal of the Palaeontological Society of India, 51(1), 43-55.

Jha, N., Mune, S. E., Bernardes-de-Oliveira, M. E. C. (2012). Palynostratigraphic considerations on Pennsylvanian interglacial microflora from Monte Mor (SP), Itararé Group, NE, Paraná Basin (Brazil) and its diachronic correlations with Indian Gondwana microflora. The Palaeobotanist, 61, 43-55.

Jha, N., Pauline Sabina, K., Tewari, R., Mehrotra, N. C. (2011). Palynological dating and correlation of surface and subsurface sediments from Wardha Valley Coalfield, Maharashtra. Journal of the Geological Society of India, 77, 137-148.

Jha, N., Tewari, R., Rajnikanth, A. (2007). Palynology of Permian Gondwana Sequence of Umrer Coalfield, Maharashtra. Journal of the Geological Society of India, 69, 851-857.
Kalkar, S. A., Bhute, S. D., Sarate, O. S. (2010). Palynoflora recorded from Makardhokada area, Nagpur district, Maharashtra. The Palaeobotanist, 59, 63-70.

Kar, R., Srivastava, C. S. (2003). Palynological delimitation of the Coal bearing lower Gondwana sediments in the Southern Parts of Tatapani Ramkola Coalfield, Chattisgarh, India. Journal of the Geological Society of India, 61, 557-564.

Kavali, P. S. (2008). Palynological studies of lower Gondwana sediments of Umrer Coalfield of Maharashtra State, India, 179. Doctoral (Thesis). Mysuru: Department of Geology, University of Mysore.

Kemp, E. M., Balme, B. E., Helby, R. J., Kyle, R. A., Playford, G., Price, P. L. (1977). Carboniferous and Permian palynostratigraphy in Australia and Antarctica: a review. The BMR Journal of Australian Geology and Geophysics, 2, 177-208.

Kyle, R. A. (1977). Palynostratigraphy of the Victoria Group, south Victoria Land, Antarctica. New Zealand Journal of Geology and Geophysics, 20, 1081-1102.

Kyle, R. A., Schopf, J. M. (1982). Permian and Triassic palynostratigraphy of the Victoria group, Trans Antarctic Mountains. In: Craddock (Ed.), Antarctic geoscience, 649659. Madison: University of Wisconsin Press.

Larsson, K., Lindstrom, S., Guy-Ohlson, D. (1990). An early Permian palynoflora from Milorgfjella, Dronning Maud Land, Antarctica. Antarctic Science, 2(4), 331-344.

Lindstrom, S. (1995). Early permian palynostratigraphy of the northern Heimefrontfjella mountain-range, Dronning Maud Land, Antarctica. Review of Palaeobotany and Palynology, 89, 359-415.

MacRae, C. S. (1988). Palynostratigraphical correlation between the Lower Karoo sequence of the Waterburg and Pafuri coal basins and the Hammanskraal plant macrofossil locality, RSA. Memoirs Geological Survey of South Africa, $75,1-217$.

Mahesh, S., Pauline Sabina, K., Mahesh Bilwa, L. (2008). Permian sediments from the subsurface sediments of lower Gondwana of Wardha Valley Coalfield, Maharashtra, India. Gondwana Geological Magazine, 23(1), 63-67.

Mahesh, S., Pauline Sabina, K., Mahesh Bilwa, L. (2011). Palynodating and correlation of subsurface sediments from bore hole CMWY-95 of Wardha Valley Coalfield, Maharashtra, Central India. The Palaeobotanist, 60, 299-307.

Mahesh, S., Pauline Sabina, K., Mahesh Bilwa, L. (2014). Palynology and depositional facet of lower Permian (Artinskian) sediments from New Majri Opencast Mine, Wardha Basin, India. Journal of the Geological Society of India, 83, 697-708. 
Marques-Toigo, M. (1988). Palinologia, bioestratigrafia e paleoecologia do Neopaleozoico da Bacia do Paraná nos estados do Rio Grande do Sul e Santa Catarina, Brasil. Doctoral (Thesis). Porto Alegre: Instituto de Geociências - UFRGS, Brazil.

Marques-Toigo, M. (1991). Palynobiostratigraphy of the southern Brazilian Neopalaeozoic Gondwana Sequence. In: H. Ulbrich, A. C. Rocha Campos (Eds.), Gondwana Seven, 503-515. Sao Paulo: Instituto de Geociências - USP.

Millsteed, B. D. (1999). Palynology of the early Permian coal-bearing deposits near Vereeniging, Free State, South Africa. Bulletin Council for Geosciences of South Africa, $124,1-81$.

Modie, B. N., Le Hérissé, A. (2009). Late Palaeozoic palynomorph assemblages from the Karoo Supergroup and their potential for biostratigraphic correlation, Kalahari Karoo Basin, Bostwana. Bulletin of Geosciences, 84(2), 337-358.

Mukherjee, B., Ghosh, A. (1972). Palyno-graphic investigations of North Karanpura Coals around Ray Bachra area, Bihar and their significance on Stratigraphy of the measures. In: A. K. Ghosh et al. (Eds.), Proceedings of Symposium on Palaepalynology and Indian Stratigraphy, 89-108. Calcutta.

Pauline Sabina, K., Mahesh Bilwa, L., Mahesh, S. (2007). A palynostratigraphic study of lower Gondwana sediments from Bandar Coalfield, Nagpur District, Maharashtra. Journal of the Geological Society of India, 69, 834-840.

Pauline Sabina, K., Mahesh Bilwa, L., Mahesh, S. (2010). Palaeoenvironmental implications of the Umrer Coalfield,Wardha Basin, Central India, through palynological studies. Gondwana Geological Magazine, 25(1), 175-180.

Price, P. L. (1983). A Permian Palynostratigraphy for Queensland. In: Permian Geology of Queensland. Symposium on Permian Geology of Queensland, 155-211. Brisbane: Geological Society of Australia Queensland Division.

Raja Rao, C. S. (1982). Coalfields of India: vol. II: coal resources of Tamil Nadu, Andhra Pradesh, Orissa and Maharashtra. Bulletin Geological Survey of India, Series $A, 45,62-100$.

Rigby, J. F., Hekel, H. (1977). Palynology of the Permian sequence in the Springsure Anticline, Central Queensland. Queensland Geological Survey Publications 352, Paleontology Paper, 37, 1-76.

Santos, R. V., Souza, P. A., Alvarenga, C. J. S., Dantas, E. L., Pimentel, M. M., Oliveira, C. G., Araújo, L. M. (2006). Shrimp U-Pb zircon dating and palynology of bentonitic layers from the Permian Iratí Formation, Paraná Basin, Brazil. Gondwana Research, 9, 456-463.
Sarate, O. S. (1985). A Karharbari mioflora from the Kamptee Coalfield, Maharashtra State, India. Geophytology, 15(2), 227-230.

Sarate, O. S. (1986). Palynological correlation of the coal seams of Pathakhera Coalfield, Madhya Pradesh, India. Geophytology, 16(2), 239-248.

Schopf, J. M., Askin, R. A. (1980). Permian and Triassic floral biostratigraphic Zones of Southern land masses: In: D. Dilcher, T. N. Taylor (Eds.), Biostratigraphy of fossil plants, 119-152. Pennsylvania: Dowde Hutchinson Ross.

Semkiwa, P., Kalkreuth, W., Utting, J., Mayagilo, F., Mpanju, F., Hagemann, H. (1998). The geology, petrology, palynology and geochemistry of Permian coal basins in Tanzania: 1. Namwele-Mkomolo, Muze and Galula coalfields. International Journal of Coal Geology, 36, 63-110.

Semkiwa, P., Kalkreuth, W., Utting, J., Mpanju, F., Hagemann, H. (2003). The geology, petrology, palynology and geochemistry of Permian coal basins in Tanzania: 2 . Songwe-Kiwira Coalfield. International Journal of Coal Geology, 55, 157-186.

Souza, P. A. (2006). Late Carboniferous palynostratigraphy of the Itararé Subgroup, northern Paraná Basin, Brazil. Review of Palaeobotany and Palynology, 138, 9-29.

Souza, P. A., Marques-Toigo, M. (2003). An overview on the palynostratigraphy of the Upper Paleozoic strata of the Brazilian Paraná Basin. Revista del Museo Argentino de Ciencias Naturales, 77, 353-365.

Srivastava, S. C. (1973). Palynostratigraphy of the Giridih Coalfield. Geophytology, 3(2), 184-194.

Srivastava, S. C. (1992). Permian palynological assemblages in the Godavari Graben. The Palaeobotanist, 40, 237-243.

Srivastava, S. C., Anand-Prakash. (1984). Palynological succession of the lower Gondwana sediments in Umaria Coalfield, Madhya Pradesh. The Palaeobotanist, 32(1), 26-34.

Srivastava, S. C., Jha, N. (1989). Palynostratigraphy of Lower Gondwana sediments in Godavari Graben, Andhra Pradesh, India. The Palaeobotanist, 37(22), 199-209.

Srivastava, S. C., Jha, N. (1995). Palynostratigraphy and correlation of Permian-Triassic sediments in Budharam Area, Godavari Graben, India. Journal of the Geological Society of India, 46, 647-653.

Stollhofen, H., Stanistreet, I. G., Bangert, B., Grill, H. (2000). Tuffs, tectonism and glacially related sea-level changes, Carboniferous-Permian, southern Namibia. Palaeogeography, Palaeoclimatology, Palaeoecology, 6, 27-50.

Sundaram, D., Nandi, A. (1984). Palaeobotanical study of Umrer Coalfield,Nagpur, Maharashtra, with special reference to biostratigraphy. In: A. K. Sharma et al. (Eds.), Symposium 
evolutionary botany and biostratigraphy, 315-321. New Delhi: Today \& Tomorrow's Printers \& Publishers.

Tewari, R. (2007). The Glossopteris flora from the Kamptee Coalfield, Wardha Basin, Maharashtra, India. Palaeontographica $B, 277,43-64$.

Tewari, R. (2008). The genus Glossopteris Brongniart from the Kamthi Formation of Camp IV area, Wardha Valley Coalfield, Wardha Basin, Maharashtra, India. Journal of Palaeontological Society of India., 53, 19-30.

Tewari, R., Pandita, S. K., Agnihotri, D., Pillai, S. S. K., Bernardes-de-Oliveira, M. E. C. (2012a). An early Permian Glossopteris flora from the Umrer Coalfield, Wardha Basin, Maharashtra, India. Alcheringa, 36, 355-371.

Tewari, R., Mehrotra, N. C., Pillai, S. S. K., Pandita, S. K., Agnihotri, D. (2012b). Gymnospermous seeds from the Barakar Formation of Umrer Coalfield, Wardha Basin, Maharashtra. The Palaeobotanist, 61(1), 123-130.

Tewari, R., Rajanikanth, A., Jha, N. (2004). Permian Gondwana megaspores of Wardha Basin, India. The Palaeobotanist, $53,35-50$.

Tiwari, R. S., Tripathi, A. (1988). Palynological zones and their climatic inference in the coal bearing Gondwana of peninsular India. The Palaeobotanist., 36, 87-101.
Tiwari, R. S. (1973). Palynological succession in the Barakar type area. Geophytology, 3(2), 166-183.

Tiwari, R. S., Srivastava, S. C., Tripathi, A., Singh, V. (1981). Palynostratigraphy of lower Gondwana sediments in Jharia Coalfield, Bihar. Geophytology, 11(2), 220-237.

Tiwari, R. S., Tripathi, A. (1992). Marker assemblage zones of spores and pollen species through Gondwana Palaeozoic and Mesozoic sequence in India. The Palaeobotanist, 40, 194-236.

Truswell, E. M. (1978). Palynology of the Permo-Carboniferous in Tasmania: an interim report. Bulletin Geological Survey Tasmania, 56, 1-39.

Utting, J. (1976). Pollen and spore assemblages in the Luwumbu Coal Formation (Lower Karoo) of the North Luangwa Valley, Zambia, and their biostratigraphic significance. Review of Palaeobotany and Palynology, 21(4), 295-315.

Vijaya. (1995). Palynostratigrphy of Permian sequence in India. In: R. S. Tiwari (Ed.), Coaliferous fuel resources of India: parameters of studies in palynology and Biopetrology 124-152. Lucknow: Birbal Sahni Institute of Palaeobotany. 